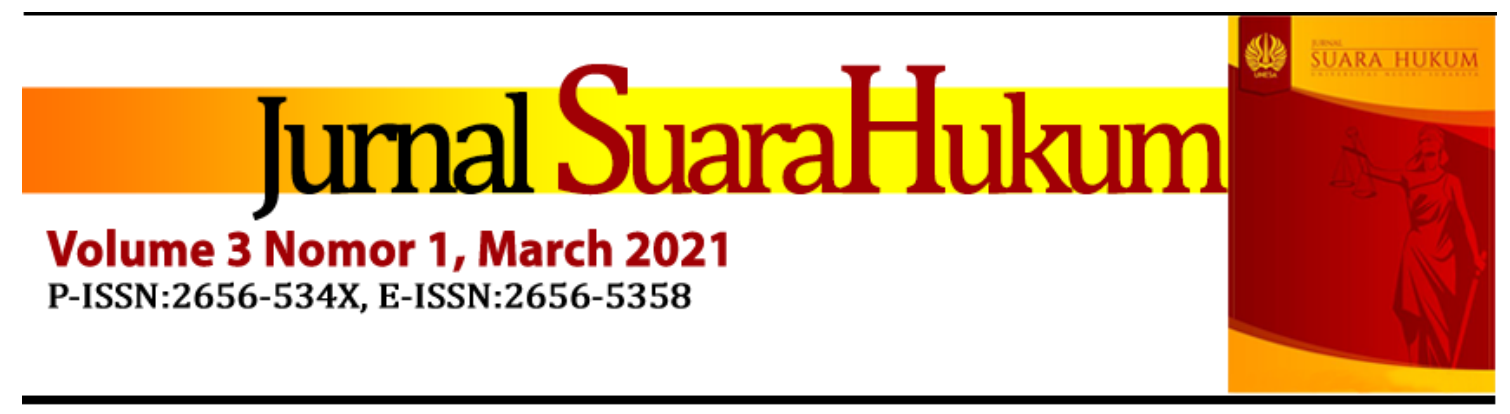

\title{
Pemenuhan Hak Anak Korban Tindak Pidana Perdagangan Orang
}

\author{
Andi Jefri Ardin ${ }^{1}$ dan Beniharmoni Harefa ${ }^{2}$ \\ ${ }^{1}$ Fakultas Hukum, Universitas Pembangunan Nasional Veteran, Jakarta, Indonesia, \\ jefrry81@gmail.com \\ ${ }^{2}$ Fakultas Hukum, Universitas Pembangunan Nasional Veteran, Jakarta, Indonesia \\ beniharefa@upnvj.ac.id
}

Article history:

Received: 2 February 2021 | Last Revision: 23 February 2021 | Accepted: 27 February 2021

\begin{abstract}
One of the most important in human trafficking is the handling of victims. By normative research methods, it discusses the fulfillment of the rights of children who are vulnerable to becoming victims. There are two legal instruments in handling child as victims, there are Law Number 21 of 2007 and Law Number 35 of 2014. Based on the research, the Law Number 21 of 2007 more fulfilling than Law Number 35 of 2014. Government Regulation Number 43 of 2017 as implementing regulations for Law Number 35 of 2014 is not much different in substance from Law Number 21 of 2007. The application of the principle of the right to life and development of children also implies the state's obligation to ensure that children must have all the necessary access like social services, physical and mental health services and education. Law Number 21 of 2007 nor Law Number 35 of 2014, not fulfilled these principles, for example regarding the education of child as victims. The law enforcement officials must pay attention to the Law Number 8 of 2010, to ensure that the defendant through confiscation of assets can fulfill the restitution for the victim's during the investigation process.
\end{abstract}

Keywords: human trafficking, victims, children's rights

Abstrak

Salah satu hal terpenting dalam menangani perdagangan orang adalah penanganan korban. Dengan menggunakan metode penelitian yuridis normatif, tulisan ini membahas tentang pemenuhan hak anak yang rentan menjadi korban perdagangan orang. Terdapat dua perangkat hukum dalam penanganan anak korban perdagangan 
orang, yaitu UU Nomor 21 Tahun 2007 dan UU Nomor 35 Tahun 2014. Berdasarkan penelitian, UU Nomor 21 Tahun 2007 ternyata lebih banyak. Pemenuhan hak anak korban perdagangan orang dibandingkan dengan UU Nomor 35 Tahun 2014 yang memiliki cakupan substansi perlindungan anak yang lebih luas. Peraturan Pemerintah Nomor 43 Tahun 2017 sebagai peraturan pelaksana UU Nomor 35 Tahun 2014 secara substansi tidak jauh berbeda dengan UU Nomor 21 Tahun 2007. Penerapan prinsip hak untuk hidup dan tumbuh kembang anak juga menyiratkan kewajiban negara untuk memastikan bahwa anak-anak harus memiliki semua akses yang diperlukan ke layanan sosial, khususnya layanan kesehatan fisik dan mental serta pendidikan. UU Nomor 21 Tahun 2007 maupun UU Nomor 35 Tahun 2014 tidak sepenuhnya memenuhi prinsip-prinsip tersebut, misalnya tentang pendidikan anak korban perdagangan orang. Untuk mengatasi kendala pelaksanaan restitusi bagi korban, aparat penegak hukum harus memperhatikan penggunaan UU Nomor 8 Tahun 2010, untuk menjamin terdakwa memenuhi restitusi bagi anak korban melalui penyitaan aset yang dimiliki.

Kata Kunci: Perdagangan Orang, Korban, Hak Anak

\section{A. PENDAHULUAN}

Salah satu bentuk kejahatan yang termasuk ke dalam pelanggaran berat Hak Asasi Manusia adalah kejahatan perdagangan orang (Suhardin, 2008). Hampir setiap negara saat ini telah memberlakukan aturan yang mengriminalisasi perdagangan orang, dan beberapa organisasi internasional, pemerintahan, dan lembaga swadaya masyarakat (LSM) juga secara aktif mendukung berbagai macam kegiatan guna menghentikan kejahatan ini. Kejahatan perdagangan orang juga merupakan salah satu dari lima kejahatan terbesar di dunia yang harus ditangani karena konsekuensinya tidak hanya pada aspek ekonomi, tetapi juga pada aspek politik, budaya dan kemanusiaan (Pramono, 2011). Perdagangan orang sering disebut sebagai "perbudakan tanpa rantai", yang tersebar luas dan sangat menguntungkan. Setelah perdagangan narkotika dan obat-obat terlarang (narkoba), perdagangan orang dikaitkan dengan perdagangan senjata ilegal sebagai industri kriminal terbesar kedua di dunia, dengan pertumbuhan paling cepat (Cantrell, 2013). 
Para pelaku perdagangan orang pada umumnya memikat korbannya dengan janji kerja kosong atau palsu dan ekonomi yang jauh lebih baik, padahal dalam kenyataannya, korban diperdagangkan untuk melakukan kerja paksa atau dijadikan pekerja seks komersial. Bahkan menurut United Nations Office on Drugs and Crime (UNODC), wanita dan anak perempuan biasanya diperdagangkan untuk dinikahkan dan dijadikan perbudakan seksual, namun laki-laki dan anak laki-laki diperdagangkan untuk dijadikan pekerja, termasuk bekerja di sektor pertambangan, sebagai kuli angkut, tentara, dan budak. Di seluruh dunia, 28 persen korban perdagangan orang adalah anak-anak (Nations, 2016).

Kejahatan perdagangan orang merupakan konsekuensi yang berakar pada kemiskinan, ketidakadilan, dan diskriminasi. Apabila dikaitkan dengan tipologi korban yang diidentifikasi menurut keadaan dan status korban, yaitu: a. unrelated victims, yaitu korban yang tidak ada hubungannya sama sekali dengan pelaku; b. provocative victims, yaitu seseorang yang secara aktif mendorong dirinya menjadi korban; c. participating victims, yaitu seseorang yang tidak berbuat, akan tetapi dengan sikapnya justru mendorong dirinya menjadi korban; d. biologically weak victims, yaitu mereka yang secara fisik memiliki kelemahan yang menyebabkan ia menjadi korban; e. socially weak victims, yaitu mereka yang memiliki kedudukan sosial yang lemah yang menyebabkan ia menjadi korban; f. self victimizing victims, yaitu mereka yang menjadi korban karena kejahatan yang dilakukannya sendiri (Schafer, 1968), maka korban kejahatan perdagangan orang merupakan "socially weak victims", karena kejahatan tersebut adalah bentuk diskriminasi dan ketidakadilan terhadap beban kerja yang harus dijalankan oleh jenis kelamin tertentu. 
Perempuan merupakan salah satu kelompok yang rentan menjadi korban dari kejahatan perdagangan orang baik dewasa maupun yang masih anak-anak (Sumirat 2017). Hal ini disinyalir karena nilai sosial budaya patriarki yang masih kuat menempatkan laki-laki dan perempuan pada kedudukan dan peran yang berbeda dan tidak setara (Sakina dan Siti A, 2017). Faktor sosial budaya tersebut yang menyebabkan terjadinya kesenjangan gender antara lain: lemahnya pemberdayaan ekonomi perempuan dibandingkan dengan laki-laki; kurangnya pengetahuan perempuan dibanding dengan laki-laki; ketidaktahuan perempuan dan anak-anak tentang apa yang sebenarnya terjadi di era globalisasi; dan minimnya hak perempuan untuk mengambil keputusan dalam keluarga atau masyarakat dibanding dengan laki-laki (Rakyat, 2004).

Kelompok yang sangat rentan untuk menjadi korban kejahatan perdagangan orang adalah anak-anak. Anak-anak yang menjadi korban perdagangan orang sering kali dieksploitasi untuk tujuan seksual, termasuk prostitusi, pornografi, dan wisata seks. Mereka juga dieksploitasi untuk perburuhan paksa, termasuk dijadikan pembantu rumah tangga, bekerja di pabrik dengan upah rendah dan kondisi buruk, dan pertanian tanaman psikotropika. Bahkan, United Nations Security Council Counter-Terrorism Committee Executive Directorate (CTED) pernah merilis sebuah laporan yang mengeksplorasi hubungan antara perdagangan orang (termasuk anak-anak) dan terorisme. Dikatakan dalam laporan tersebut bahwa perdagangan orang merupakan alat untuk mengumpulkan dana untuk tujuan teroris (CTED, 2019).

Pemerintah Indonesia sendiri telah berusaha melakukan berbagai upaya untuk menangani masalah perdagangan anak, namun upaya-upaya tersebut belum menunjukkan hasil yang optimal karena kasus perdagangan anak yang terjadi di Indonesia justru semakin marak terjadi. Data Komisi Perlindungan Anak Indonesia (KPAI) tahun 2019 
mencatat ada 244 kasus korban anak kejahatan perdagangan orang dan eksploitasi, termasuk korban anak pekerja, dengan korban anak perdagangan sebanyak 56 kasus dan korban anak pekerja 53 kasus (Puspita, 2018). Bahkan, di tengah masa pandemi penyakit corona virus (Covid 19) saat ini, KPAI menemukan kasus kejahatan perdagangan anak yang melibatkan remaja berusia 15 dan 16 tahun di Jakarta, yang akan diperkerjakan di Bali untuk prostitusi (Putri, 2020). Ini memperlihatkan betapa memprihatinkannya kejahatan perdagangan orang, khususnya anak-anak di Indonesia.

Salah satu hal yang terpenting namun nyaris terlupakan dalam penanganan perdagangan orang adalah penanganan korban. Korban kejahatan merupakan pihak yang paling menderita (Yulia, 2016), namun faktanya belum memperoleh perlindungan sebanyak yang diberikan oleh undang-undang kepada pelaku kejahatan. Masalah keadilan dan penghormatan hak asasi manusia tidak hanya berlaku terhadap pelaku kejahatan saja, tetapi juga korban kejahatan (Yuliartini, 2015). Kejahatan dapat mengakibatkan ketidakseimbangan dalam diri korban atau keluarganya, misalnya dari aspek ekonomi, yaitu apabila korban merupakan tumpuan hidup keluarga, aspek psikis berwujud pada munculnya trauma pada diri korban (Mansur, 2008). Untuk menyeimbangkan kondisi korban tersebut, maka harus ditempuh upaya pemulihan baik finansial, medis, psikis. Pada umumnya korban dirumuskan sebagai seseorang yang menderita kerugian fisik, mental, emosional, maupun ekonomi. Belum optimalnya perhatian dan pelayanan terhadap korban kejahatan, merupakan tanda belum atau kurang adanya keadilan dan pengembangan kesejahteraan dalam masyarakat tersebut (Gosita, 1993).

Dalam Undang-undang Nomor 21 Tahun 2007 Tentang Pemberantasan Tindak Pidana Perdagangan Orang (UU No. 21 Tahun 2007) diatur mengenai ganti rugi (Muladi, 2002) atau hak restitusi (Pasal 48), yakni pembayaran ganti kerugian yang dibebankan 
pada pelaku berdasarkan putusan pengadilan yang berkekuatan hukum tetap atas kerugian materiel dan/atau imateriel yang diderita korban atau ahli warisnya. Dengan dimuatnya hak-hak korban tindak pidana perdagangan orang, berarti menjadi kewajiban negara untuk melindungi dan memenuhi hak seluruh warga negaranya, termasuk anak. Berbagai perumusan tindak pidana dalam suatu peraturan perundang-undangan tersebut (idealnya) menunjukkan adanya perlindungan hukum dan hak asasi korban (Arief, 1998).

Restitusi sebagaimana prinsip pemulihan dalam keadaan semula adalah upaya untuk memastikan bahwa korban suatu tindak pidana harus dikembalikan ke kondisi semula sebelum tindak pidana terjadi (Bimantara dan Sumadi, 2018), meskipun tidak mungkin korban dapat kembali ke kondisi semula dengan sempurna. Prinsip ini menegaskan bahwa bentuk pemulihan korban harus selengkap mungkin dan mencakup berbagai aspek yang diakibatkan oleh akibat tindak pidana. Dengan restitusi, korban dapat dikembalikan ke kebebasan, hak hukum, status sosial, kehidupan keluarga dan kewarganegaraan, kembali ke tempat tinggalnya, memulihkan pekerjaannya, dan memulihkan asetnya (Anchori, 2020). Dalam praktiknya, di hampir semua negara, konsep restitusi dikembangkan dan diberikan kepada korban kejahatan atas penderitaannya sebagai korban kejahatan. Dalam konsep ini, korban dan keluarganya harus mendapatkan kompensasi yang adil dan pantas dari pihak yang bersalah atau pihak ketiga yang bertanggung jawab. Kompensasi ini mencakup pengembalian harta benda atau pembayaran atas kerusakan atau kerugian yang diderita, kompensasi atas biaya yang timbul akibat jatuhnya korban, penyediaan layanan dan hak untuk pemulihan (Supriyadi Widodo Eddyono, 2014).

Anak yang menjadi korban kejahatan perdagangan orang, tidak bisa disamakan begitu saja dengan orang dewasa. Anak yang menjadi korban suatu kejahatan, dapat 
dipastikan akan mengalami gangguan dalam tumbuh dan kembangnya, terutama kondisi psikis mereka. Anak adalah ciptaan Tuhan Yang Maha Kuasa yang harus dilindungi harga diri dan martabatnya, serta dijamin hak hidupnya untuk tumbuh dan berkembang sesuai fitrah dan kodratnya. Agar setiap anak kelak mampu memikul tanggung jawab tersebut, maka ia perlu mendapat kesempatan yang seluas-luasnya untuk tumbuh dan berkembang secara optimal, baik fisik, mental maupun sosial, dan berakhlak mulia, perlu dilakukan upaya perlindungan serta untuk mewujudkan kesejahteraan anak dengan memberikan jaminan terhadap pemenuhan hak-haknya serta adanya perlakuan tanpa diskriminasi. Oleh karena itu, segala bentuk perlakuan yang mengganggu dan merusak hak-hak dasarnya dalam berbagai bentuk pemanfaatan dan eksploitasi yang tidak berperikemanusiaan sudah sepatutnya segera dihentikan tanpa terkecuali (Sumirat, 2017).

Hak restitusi yang diatur dalam UU No. 21 Tahun 2007, ternyata belum sepenuhnya mengakomodir perlindungan dan pemenuhan hak anak yang menjadi korban kejahatan perdagangan orang. Kelemahan perlindungan anak yang menjadi korban perdagangan ini kemudian coba diatasi dengan terbitnya Undang-undang Nomor 35 Tahun 2014 tentang Perubahan atas Undang-undang Nomor 23 Tahun 2002 tentang Perlindungan Anak (UU No. 35 Tahun 2014). Berdasarkan amanat Pasal 71D UU No. 35 Tahun 2014, pemerintah kemudian menindaklanjutinya dengan menerbitkan peraturan pelaksana dalam Peraturan Pemerintah Nomor 43 Tahun 2017 tentang Pelaksanaan Restitusi Bagi Anak yang Menjadi Korban Tindak Pidana (PP No. 43 Tahun 2017). Kedua undang-undang ini (UU No. 21 Tahun 2007 dan UU No. 35 Tahun 2014) pada dasarnya berusaha untuk memenuhi hak anak yang menjadi korban kejahatan (pemberian hak restitusi). 
UU No. 21 Tahun 2007 anak hanya menjadi korban kejahatan perdagangan orang, maka dalam UU No. 35 Tahun 2014 anak menjadi korban kejahatan secara umum. Untuk itu menarik untuk dikaji mengenai pemenuhan hak anak yang menjadi korban perdagangan orang pasca berlakunya UU No. 35 Tahun 2014 tersebut, karena antara UU No. 21 Tahun 2007 dan UU No. 35 Tahun 2014 adalah 2 (dua) undang-undang yang berbeda secara substansi. Penelitian mengenai anak sebagai korban kejahatan perdagangan orang sudah banyak dilakukan, seperti misalnya mengenai perlindungan hukum terhadap korban trafficking anak dan perempuan (Abdullah, 2017) dan mengenai perlindungan terhadap anak korban trafficking (Anisa Soraya, 2020). Tulisan ini berbeda dengan penelitian-penelitian tersebut karena bukan dimaksudkan membahas penerapan unsur-unsur dalam tindak pidana perdagangan orang dalam kedua undang-undang tersebut oleh penegak hukum, melainkan membahas persoalan mana yang lebih ideal untuk diterapkan dalam rangka pemenuhan hak anak yang menjadi korban kejahatan perdagangan orang.

\section{B. METODE PENELITIAN}

Untuk menganalisis dan membahas permasalahan tersebut, tulisan ini menggunakan penelitian hukum normatif (yuridis normatif), karena didasari pertimbangan untuk mengkaji kaidah-kaidah atau aturan-aturan (Ibrahim, 2011). Aturan hukum yang akan dikaji adalah Undang-undang Nomor 21 Tahun 2007 tentang Pemberantasan Tindak Pidana Perdagangan Orang dan Undang-undang Nomor 35 Tahun 2014 tentang perubahan terhadap atas Undang-undang Nomor 23 Tahun 2002 tentang Perlindungan Anak. Hal ini juga dilakukan untuk mengetahui kebijakan perlindungan anak dalam kasus trafficking, kemudian melakukan pendekatan perundangan-undangan (statute approach), dengan menelaah semua undang-undang dan regulasi yang 
bersangkut paut dengan isu hukum. Pendekatan ini digunakan untuk membantu mempelajari konsistensi dan kesesuaian antara suatu undang-undang dengan undangundang lainnya (Marzuki, 2005). Penelitian ini juga menggunakan pendekatan sejarah yaitu penelitian atau kajian perkembangan produk hukum berdasarkan urutan periodisitas atau fakta sejarah yang melatarbelakanginya, dan pendekatan konseptual yaitu penelitian tentang konsep hukum seperti sumber hukum, fungsi hukum, lembaga hukum (Nasution, 2008).

\section{HASIL DAN PEMBAHASAN}

Definisi yang disepakati mengenai kejahatan perdagangan orang muncul pertama kalinya pada tahun 2000 dalam Protocol to Prevent, Suppress, and Punish Trafficking in Persons, Especially Women and Children the United Nations Convention against Transnational Organized Crime (Protokol Palermo) yang mendefinisikan perdagangan orang sebagai perekrutan, pengiriman, pemindahan, penampungan atau penerimaan seseorang, dengan ancaman atau penggunaan kekerasan atau bentuk-bentuk lain dari pemaksaan, penculikan, penipuan, kebohongan atau penyalahgunaan kekuasaan atau posisi rentan atau memberi atau menerima pembayaran atau memperoleh keuntungan agar dapat memperoleh persetujuan dari seseorang yang berkuasa atas orang lain, untuk tujuan eksploitasi (Moeri, 2018). Eksploitasi termasuk, paling tidak, eksploitasi untuk melacurkan orang lain atau bentuk-bentuk lain dari eksploitasi seksual, kerja atau pelayanan paksa, perbudakan atau praktik-praktik serupa perbudakan, penghambaan atau pengambilan organ tubuh (Pasal 4 Protokol Palermo).

Pengertian ini tidak menekankan pada perekrutan dan pengiriman yang menentukan suatu perbuatan sebagai tindak pidana perdagangan orang, tetapi juga kondisi eksploitasi terkait ke dalam mana orang diperdagangkan (Farhana, 2010). Protokol tersebut 
merupakan instrumen global pertama yang mengikat secara hukum dengan definisi yang disepakati tentang perdagangan orang. Maksud di balik definisi ini adalah untuk memfasilitasi konvergensi dalam pendekatan nasional terkait dengan pembentukan hukum nasional yang akan mendukung kerjasama internasional yang efisien dalam menyelidiki dan menuntut kasus perdagangan orang. Tujuan tambahan dari Protokol ini adalah untuk melindungi dan membantu para korban perdagangan orang dengan penghormatan penuh terhadap hak asasi mereka (Jansson, 2014).

Anak merupakan kelompok yang sangat rentan menjadi korban perdagangan orang selain perempuan. Maraknya kasus perdagangan anak saat ini sudah sangat memprihatinkan, dimana anak yang seharusnya diperlakukan dengan baik justru dimanfaatkan untuk tujuan tertentu. Tidak peduli siapa mereka, di mana mereka tinggal, bahasa apa yang mereka gunakan, apa agama mereka, apa yang mereka pikirkan, seperti apa penampilan mereka, apakah mereka laki-laki atau perempuan, jika mereka memiliki kecacatan, apakah mereka kaya atau miskin, dan tidak peduli siapa orang tua atau keluarganya atau apa yang dipercaya atau dilakukan oleh orang tua atau keluarganya. Tidak ada anak yang harus diperlakukan tidak adil untuk alasan apapun. Oleh karena itu, segala bentuk perlakuan yang merusak hak-hak dasarnya dalam bentuk berbagai penggunaan dan eksploitasi yang tidak manusiawi sudah seharusnya segera dihentikan. Apalagi dalam kasus perdagangan orang, posisi anak benar-benar tidak berdaya dan lemah, baik secara fisik maupun mental, bahkan terkesan pasrah jika diperlakukan tidak sebagaimana semestinya (Takariawan, 2017).

Anak-anak termasuk ke dalam kelompok rentan. Untuk itulah, dengan mudahnya anak-anak menjadi korban para trafficking, terutama mereka yang berasal dari orang yang tidak mampu secara ekonomi, mereka yang berpendidikan dan berpengetahuan terbatas, 
yang terlibat masalah ekonomi, politik dan sosial yang serius, anggota keluarga yang menghadapi krisis ekonomi seperti hilangnya pendapatan orang tua, orang tua sakit keras, atau meninggal dunia. Perdagangan anak pada umumnya dilakukan untuk tujuan berikut (Sharma, 2015):

a. Eksploitasi Seksual: Anak-anak dieksploitasi secara seksual dengan memaksa mereka menjadi pelacur baik atas dasar status ekonomi mereka. Anak-anak juga dilecehkan melalui pornografi, bride trafficking, panti pijat, rumah bordil, layanan escort, dan sebagainya.

b. Tenaga Kerja: anak-anak juga dipekerjakan dalam pekerjaan rumah tangga, restoran dan hotel, pertanian, pekerjaan konstruksi, pertambangan, dan bahkan sebagai penyelundup senjata dan narkotika (Organization, 2016).

c. Adopsi/Pencucian/Pernikahan: Anak-anak diperdagangkan/dicuci dan dilecehkan melalui adopsi dan pernikahan Intra/Antar-Negara. Child laundering (Román and Rotabi, 2019) atau "pencucian anak” terjadi ketika anak-anak diambil secara ilegal dari keluarga kelahiran melalui pembelian atau penculikan anak dan "dicuci" melalui sistem adopsi sebagai "yatim piatu" dan kemudian sebagai "adopsi”.

d. Surrogacy : anak perempuan dan perempuan muda dari negara berkembang dibayar/diculik/ditahan untuk mendapatkan uang tebusan dari tahun ke tahun untuk dijual kepada pasangan yang tidak subur atau orang-orang milik negara kaya. Dalam kasus-kasus tertentu para perempuan dipaksa oleh keadaan untuk berpisah dengan anak-anak mereka untuk melunasi hutang mereka. Di bawah perampasan altruisme, ibu pengganti tumbuh subur di negara 
berkembang dan anak-anak berusia satu hingga dua hari dikeluarkan dari ibu mereka dan diperdagangkan di dalam dan di luar negeri (Hyun, 2018).

e. Tentara Anak: Anak-anak yang digunakan dalam pertempuran adalah perwujudan kontemporer dari perbudakan dan bentuk perdagangan orang yang serius dan menguntungkan seperti kejahatan internasional perdagangan perempuan dan narkoba. Prajurit anak terdaftar sebagai "salah satu bentuk pekerjaan terburuk untuk anak" dalam Konvensi ILO 182 tentang Bentukbentuk Pekerjaan Terburuk untuk Anak. Anak-anak yang berpindah tempat karena mereka mengungsi akibat perang atau kerusuhan sipil sangat rentan terhadap penculikan dan pekerja anak paksa. Pada tahun 2000 sekitar 13 juta anak mengungsi akibat konflik perang. Sejumlah besar anak berusia 11-15 tahun telah menjadi tentara anak di 50 negara aneh seperti Afghanistan, Chad, Sudan, dan Somalia (Tiefenbrun, 2007).

f. Perdagangan Organ: Kasus-kasus peredaran organ anak semakin mengerikan karena korbannya adalah anak-anak yang sangat rentan secara fisik dan tidak berdaya. Misalnya, dalam kebanyakan kasus perdagangan organ pada orang dewasa, para korban dibebaskan setelah pengambilan organ, dalam kasuskasus perdagangan organ anak yang dikonfirmasi, pengambilan organ dari anak-anak yang diperdagangkan atau diculik itu merenggut nyawa mereka.

Perdagangan anak merupakan pelanggaran hak anak untuk hidup, bertahan hidup dan berkembang, karena anak-anak yang dipaksa melakukan eksploitasi melakukan tugas-tugas yang membahayakan kesehatan dan perkembangan harmonis mereka. Pelaksanaan prinsip hak untuk hidup, kelangsungan hidup dan perkembangan juga menyiratkan kewajiban negara untuk memastikan bahwa Anak-anak yang menjadi 
korban perdagangan memiliki akses ke layanan sosial yang sesuai, khususnya layanan kesehatan fisik dan mental serta pendidikan.

Memerangi perdagangan anak merupakan kewajiban bagi Negara untuk memenuhi ketentuan Convention on the Rights of the Child (UNICEF, 2007) (Konvensi Hak-Hak Anak), namun bukan berarti melakukan segara cara untuk menuntut para pelaku perdagangan, terlebih jika hal itu membahayakan anak-anak atau membawa risiko lebih lanjut membuat mereka mengalami trauma. Sebenarnya yang terpenting adalah menyiapkan program dan kebijakan pencegahan yang ditujukan untuk mengatasi akar penyebab terjadinya perdagangan anak. Dalam hal ini, undang-undang merupakan instrumen yang berfungsi memberikan mandat kepada lembaga dan/atau kementerian tertentu dengan tanggung jawab untuk merancang dan melaksanakan program-program tersebut. Rezim anti-perdagangan orang harus memberikan perlindungan bagi setiap manusia yang berusia di bawah 18 tahun, tanpa kecuali. Ketentuan perlindungan anak juga seharusnya diberlakukan bagi anak perempuan korban perdagangan yang sudah menikah, meskipun hukum mungkin menganggapnya sebagai orang dewasa karena status perkawinannya (Afrizal, 2019).

Asas-asas negara hukum mensyaratkan bahwa negara hanya dapat menghukum seseorang beranjak dari atau selaras dengan tingkat ketercelaan perbuatan dan kesalahan pelaku. Indonesia sebagai negara hukum, melihat perdagangan orang, khususnya perempuan dan anak, sebagai sebuah perbuatan yang sangat bertentangan dengan harkat dan martabat manusia dan melanggar hak asasi manusia serta merupakan ancaman terhadap masyarakat, bangsa, dan negara, serta terhadap norma-norma kehidupan yang dilandasi penghormatan terhadap hak asasi manusia. Berdasarkan rasionalitas ketercelaan praktik perdagangan orang tersebut, maka kemudian diberlakukanlah UU No. 21 Tahun 
2007. Selain itu, sebagaimana penjelasannya, undang-undang ini juga memperhatikan penderitaan korban akibat kejahatan perdagangan orang dalam bentuk hak restitusi yang harus diberikan pelaku sebagai kompensasi bagi korban. Undang-undang ini juga mengatur hak-hak korban atas rehabilitasi medis dan sosial, repatriasi serta reintegrasi yang harus dilakukan oleh negara, terutama bagi mereka yang mengalami penderitaan fisik, psikologis dan sosial akibat perdagangan orang.

Dalam konsideransnya, undang-undang ini menegaskan bahwa perdagangan orang, khususnya perempuan dan anak, merupakan tindakan yang bertentangan dengan harkat dan martabat manusia dan melanggar hak asasi manusia, sehingga harus diberantas, namun ternyata substansinya tidak menegaskan pembedaan korban perdagangan orang (khususnya anak). Antara laki-laki atau perempuan, dewasa atau anak-anak, semuanya kemudian digeneralisasi sebagai subyek hukum korban yang harus dipenuhi haknya oleh pelaku dan negara. Terutama bagi korban anak, ternyata dalam undang-undang ini belum mengatur mengenai masalah kebutuhan seorang anak yang menjadi korban perdagangan orang, misalnya masalah pendidikan anak, pendampingan dalam proses tumbuh kembang anak, pengasuhan anak yang ternyata yatim piatu dan sebagainya. Dalam praktik pun ternyata, untuk menerapkan hak restitusi kepada korban, belum dapat dimaksimalkan oleh aparat penegak hukum (Marasabessy, 2016).

Berdasarkan hasil penelitian yang pernah dilakukan Sondang Kristine, penegak hukum yang menangani perkara perdagangan orang kurang maksimal dalam memperjuangkan hak restitusi korban, yaitu hanya sebatas menanyakan atau memberitahukan adanya hak restitusi yang diperoleh korban. Selama proses penyidikan, penyidik memberitahukan korban mengenai hak restitusi berupa ganti kerugian baik materiel maupun imateriel sebagai akibat dari tindak pidana perdagangan orang, dalam 
berita acara pemeriksaan saksi korban. Selanjutnya pada tahap penuntutan, Penuntut Umum menanyakan pada saksi korban mengenai kerugian yang diderita baik materiel maupun imateriel dan memberitahukan bahwa saksi korban memiliki hak restitusi dan mencantumkan restitusi tersebut dalam surat tuntutannya. Kemudian dalam putusan pengadilan, memuat restitusi tersebut dan mengabulkannya sebesar yang diminta dalam surat tuntutan Penuntut Umum. Namun, pelaksanaan putusan terhadap pemenuhan hak restitusi tersebut tidak dilaksanakan dan pelaku lebih memilih untuk menjalankan hukuman pidana kurungan pengganti, sehingga hak restitusi korban hanya sampai sebatas putusan belaka atau hanya di atas kertas saja, apalagi terkait dengan kasus tersebut tidak ada aset milik terpidana yang disita oleh penyidik (Lukwira, 2017).

UU No. 35 Tahun 2014 diberlakukan guna lebih meningkatkan perlindungan terhadap anak sebagai "penyempurnaan" UU No. 23 Tahun 2002. Substansi paling penting dalam UU No. 35 Tahun 2014 ini adalah adanya pengaturan mengenai perlindungan khusus kepada anak, yang salah satunya mengatur pemberian perlindungan khusus kepada korban anak penculikan, penjualan, dan/atau perdagangan (Pasal 59 ayat (2) huruf h). Selanjutnya, Pasal 71D ayat (1) UU No. 35 Tahun 2014 juga mengatur mengenai hak restitusi anak yang menjadi korban perdagangan orang Pasal 71D ayat (1). Ketentuan-ketentuan tersebut, tidak diatur sebelumnya dalam UU No. 23 Tahun 2002. Selain ketentuan-ketentuan tersebut, UU No. 35 Tahun 2014 dapat dikatakan telah memperluas cakupan tentang perlindungan anak di Indonesia, yang memang sudah seharusnya dilakukan oleh negara.

Berdasarkan amanat Pasal 71D UU No. 35 Tahun 2014, pemerintah kemudian menindaklanjutinya dengan menerbitkan peraturan pelaksana dalam PP No. 43 Tahun 2017. Peraturan ini sangat lengkap mengatur tentang restitusi, yang terbagi dalam 4 
(empat) bab dan memiliki 23 Pasal di dalamnya, namun secara substansi ternyata sama saja dengan pengaturan restitusi dalam UU No. 21 Tahun 2007. Perbedaan minornya hanya pada keterlibatan Lembaga Perlindungan Saksi dan Korban (LPSK) saja, dan itupun bisa/boleh dilibatkan bisa/boleh juga tidak. Pasal 5 ayat (3) PP No. 43 Tahun 2017 mengatur bahwa selain melalui tahap penyidikan atau penuntutan, permohonan Restitusi “dapat” diajukan melalui LPSK sesuai dengan ketentuan peraturan perundang-undangan. Dengan demikian, permasalahan penerapan restitusi dalam praktik sebagaimana dikemukakan Sondang Kristine, PP No. 43 Tahun 2017 tidak memberikan solusi yang signifikan. Mekanisme dan prosedur pengajuan restitusi serta pelaksanaannya juga sebenarnya masih menyisakan persoalan, karena LPSK tidak termasuk dalam sistem peradilan pidana, dan bukan merupakan aparat penegak hukum yang memiliki kewenangan eksekutoral (Marasabessy, 2016).

UU No. 35 Tahun 2014 yang telah memperluas cakupan perlindungan anak, ternyata tidak lebih baik memberikan pemenuhan hak korban anak perdagangan orang dibandingkan UU No. 21 Tahun 2007. Mengenai anak yang menjadi korban perdagangan orang, UU No. 35 Tahun 2014 justru hanya memenuhi hak anak melalui restitusi, yang kemudian dibuatkan peraturan pelaksanaannya dalam PP No. 43 Tahun 2017. UU No. 21 Tahun 2007 yang telah mengategorikan korban anak sama dengan korban orang dewasa, justru lebih memenuhi hak anak, misalnya dalam Pasal 51 yang mengatur bahwa korban (anak) berhak memperoleh rehabilitasi kesehatan, rehabilitasi sosial, pemulangan, dan reintegrasi sosial dari pemerintah apabila yang bersangkutan mengalami penderitaan baik fisik maupun psikis akibat tindak pidana perdagangan orang. UU No. 21 Tahun 2007, meskipun belum secara komprehensif, justru lebih memberikan perlindungan khusus 
kepada anak dibandingkan UU No. 35 Tahun 2014 tentang perlindungan anak juncto PP No. 43 Tahun 2017.

Politik hukum terhadap anak yang menjadi korban tindak pidana perdagangan orang ternyata belum mampu sepenuhnya dapat memenuhi hak anak. Kepentingan terbaik anak juga belum menjadi pertimbangan utama dalam semua tindakan yang menyangkut anak. Dalam penanganan tindak pidana perdagangan orang, arah kebijakan negara terkesan lebih memprioritaskan menangkap dan kemudian menuntut para pelaku perdagangan orang, yang merupakan bagian dari jaringan kejahatan terorganisir. Dalam sistem pembuktian pidana yang dianut saat ini (Febriana Nur Hidayati, 2016), korban anak dalam beberapa kasus masih diperlukan kesaksiannya di depan persidangan, meskipun itu bukan untuk kepentingan terbaik anak mengingat trauma yang mereka derita.

Anak yang telah menjadi korban perdagangan orang, perlu kembali ke perasaan normal dalam hidup mereka. Selain itu, anak-anak yang diperdagangkan kemungkinan besar tidak memiliki akses pendidikan. Hak atas pendidikan korban anak perlu dipenuhi oleh negara, apapun kewarganegaraan korban perdagangan orang. Pemenuhan hak ini mungkin memerlukan adaptasi undang-undang pendidikan untuk memastikan bahwa pendidikan dapat diakses oleh semua anak dalam yurisdiksi Negara. Misalnya, undangundang negara Rusia menetapkan bahwa Komisi Federal, komisi regional, suaka dan pusat harus segera memberi tahu otoritas eksekutif yang bertanggung jawab atas masalah pengasuhan dan perwalian, jika mereka menerima informasi tentang korban anak perdagangan, untuk memastikan dan melindungi hak anak. Rancangan undang-undang tersebut juga menyatakan bahwa Anak-anak yang menjadi korban perdagangan harus 
diberi kesempatan untuk bersekolah sesuai dengan undang-undang federal tentang pendidikan (Sedletzki, 2008).

Kerangka hukum suatu negara idealnya dapat mengintegrasikan kepentingan terbaik anak sebagai prinsip lintas sektoral, dan dalam undang-undang yang terkait dengan masalah perdagangan orang, prinsip tersebut harus ditegaskan kembali sebagai prinsip yang lebih unggul dari semua pertimbangan lainnya. Sebagai perbandingan, di Bulgaria, undang-undang membentuk komisi nasional dan komisi lokal/daerah untuk memerangi perdagangan orang. Komisi nasional terdiri dari perwakilan tingkat tinggi dari kementerian tenaga kerja, dalam negeri, keadilan, kesehatan, dan pendidikan, serta badan perlindungan anak dan komisi penanggulangan perilaku anti-sosial remaja dan anak di bawah umur. Komisi nasional juga termasuk anggota Mahkamah Agung, Kejaksaan dan Badan Penyidik Nasional, serta perwakilan dari LSM dan organisasi internasional yang diwakili di negara yang bekerja di bidang pencegahan dan pemberantasan perdagangan orang. Komisi lokal/daerah terdiri dari tiga hingga tujuh anggota yang ditunjuk oleh Walikota dan melibatkan perwakilan pemerintah daerah yang terlibat dalam pendidikan, masalah kesehatan dan kebijakan sosial, departemen perlindungan anak, perwakilan polisi, LSM, guru, psikolog, pengacara, dokter, dll. Seorang perwakilan dari Kejaksaan harus menghadiri sidang Komisi Lokal (Sedletzki, 2008). Berbeda dengan Indonesia, penanganan tindak pidana orang masih sangat bergantung pada kebijakan pemerintah pusat dan lebih mengedepankan aspek yuridis, yakni peranan aparat penegak hukum.

Mengacu pada hukum positif Indonesia saat ini terkait dengan perdagangan orang termasuk anak, UU No. 21 Tahun 2007 lebih memberikan pemenuhan hak anak dibandingkan UU No. 35 Tahun 2014, setidaknya untuk saat ini. Adapun masalah penerapan restitusi, penegak hukum dapat memaksimalkan pembayaran restitusi oleh 
pelaku dengan menerapkan Undang-undang Nomor 8 Tahun 2010 tentang Pencegahan dan Pemberantasan Tindak Pidana Pencucian Uang (UU No. 8 Tahun 2010), karena dalam Pasal 2 ayat (1) huruf 1 telah dinyatakan bahwa hasil tindak pidana adalah harta kekayaan yang diperoleh dari tindak pidana perdagangan orang. Undang-undang juga dapat menjerat jika perdagangan orang dilakukan oleh korporasi.

Pada umumnya pelaku tindak pidana berusaha menyembunyikan atau menyamarkan asal usul Harta Kekayaan yang merupakan hasil dari tindak pidana dengan berbagai cara agar Harta Kekayaan hasil tindak pidananya susah ditelusuri oleh aparat penegak hukum sehingga dengan leluasa memanfaatkan Harta Kekayaan tersebut baik untuk kegiatan yang sah maupun tidak sah, termasuk pelaku perdagangan orang. Oleh sebab itu, penyidik atau Penuntut Umum memberikan petunjuknya kepada penyidik, seharusnya mulai menerapkan ketentuan Pasal 3 sampai dengan Pasal 10 UU No. 8 Tahun 2010, untuk kemudian melalukan penyitaan harta kekayaan pelaku sebagaimana diatur dalam Pasal 39 ayat (1) Kitab Undang-undang Hukum Acara Pidana (KUHAP). Dengan melakukan penyitaan harta kekayaan pelaku perdagangan orang terlebih dahulu, nantinya dapat lebih memudahkan eksekusi pembayaran restitusi kepada korban. Selain itu, Pasal 69 UU No. 8 Tahun 2010 mengatur bahwa untuk dapat dilakukan penyidikan, penuntutan, dan pemeriksaan di sidang pengadilan terhadap tindak pidana Pencucian Uang tidak wajib dibuktikan terlebih dahulu tindak pidana asalnya.

\section{PENUTUP}

Terdapat 2 (dua) instrumen hukum dalam penanganan korban anak kejahatan perdagangan orang, yakni UU No. 21 Tahun 2007 dan UU No. 35 Tahun 2014. Dalam pemenuhan hak korban anak, UU No. 21 Tahun 2007, meskipun masih mendudukkan 
korban anak sama dengan korban dewasa, justru lebih memberikan atau memenuhi hak anak sebagai korban. UU No. 35 Tahun 2014 sebagai aturan yang memiliki cakupan lebih luas tentang perlindungan anak, ternyata tidak lebih baik dibandingkan UU No. 21 Tahun 2007. Ironisnya, PP No. 43 Tahun 2017 sebagai peraturan pelaksana UU No. 35 Tahun 2014 yang diharapkan dapat memenuhi hak anak, ternyata secara substansi tidak jauh berbeda dengan UU No. 21 Tahun 2007. PP No. 43 Tahun 2017 belum terlalu jauh menjangkau pemikiran bahwa masa depan anak yang menjadi korban perdagangan, semata-mata bukan hanya persoalan uang atau ganti rugi. Pengalaman traumatis korban anak perdagangan orang yang akan dibawa seumur hidup mereka, tentu saja tidak dapat disembuhkan atau diselesaikan dengan ganti rugi saja. Pada hakikatnya, pelaksanaan prinsip hak anak untuk kelangsungan hidup dan perkembangan juga menyiratkan kewajiban negara untuk memastikan bahwa anak memiliki akses ke layanan sosial yang sesuai, khususnya layanan kesehatan fisik dan mental serta pendidikan, tetapi baik UU No. 21 Tahun 2007 maupun UU No. 35 Tahun 2014 belum memenuhi harapan, terutama tentang pendidikan korban anak. Mengenai kendala penerapan restitusi kepada korban, aparat penegak hukum penulis merekomendasikan agar aparat penegak hukum serius mempertimbangkan untuk menerapkan instrumen UU No. 8 Tahun 2010, guna memastikan bahwa restitusi bagi korban anak, dapat dipenuhi oleh terdakwa melalu penyitaan harta kekayaan saat proses penyidikan. 


\section{DAFTAR PUSTAKA}

\section{Artikel Jurnal}

Abdullah, Dadang. (2017). Perlindungan Hukum Terhadap Korban Trafficking Anak dan Perempuan. Al'Adl, IX(2), 231-243.

Afrizal, T. Y. (2019). Dispensasi Perkawinan di Bawah Umur dalam Perspektif Hukum Islam dan Perundang-Undangan Bidang Perkawinan di Mahkamah Syar'iyah Lhokseumawe. Jurnal Hukum Acara Perdata, 5(1), 96.

Anchori, Yusup. (2020). Perlindungan Hukum Korban Tindak Pidana Yang Dilakukan Oleh Orang Dengan Gangguan Jiwa (Odgj) Dihubungkan Dengan Tujuan Negara Hukum Dalam Sistem Pemidanaan di Indonesia. Jurnal Syntax Admiration, 1(8), 1183-1200.

Bimantara, I.G.A Dian dan I.P. Sudarma Sumadi. (2018). Konsep Restitusi Terhadap Perlindungan Korban Tindak Pidana di Indonesia. Kertha Wicara, 7(2), 1-5.

Febriana Nur Hidayati, D. (2016). Kekuatan Alat Bukti Saksi Korban Yang Masih dibawah Umur dan Tidak Disumpah Dalam Persidangan Perkara Pencabulan Anak. Jurnal Verstek, 4(2), 72.

Lukwira, A. L. (2017). Restitusi Sebagai Pidana Tambahan yang Bermanfaat Bagi Pelaku dan Korban Tindak Pidana. Deviance Jurnal Kriminologi, 1(1), 56-70.

Marasabessy, F. (2016). Restitusi Bagi Korban Tindak Pidana: Sebuah Tawaran Mekanisme Baru. Jurnal Hukum \& Pembangunan, 45(1), 53.

Moeri, M.N Chrisna, Dkk. (2016). Implementasi Protokol Palermo Dalam Menanggulangi Permasalahan Tenaga Kerja Wanita Indonesia Yang Menjadi Korban Human Trafficking. Universitas Udayana. Jurnal Hubungan Internasional, $1(1), 1-1-5$.

Putri, S.A dan Agus Takariawan. (2017). Pemahaman Mengenai Perlindung Korban Perdagangan Anak (Trafficking) dan Pekerja Anak Di Bawah Umur Di Jawa Barat. Dharmakarya, 6(4), 245-249.

Román, Beatriz San and Karen S. Rotabi, (2019). Rescue, Red Tape, Child Abduction, Illicit Adoptions, and Discourse: Intercountry Adoption Attitudes In Spain. International Social Work, 62(1), 198-211.

Sakina, Ade Irma dan Dessy Hasanah Siti A. (2017). Menyoroti Budaya Patriarki Di Indonesia. Share: Social Work Jurnal, 7(1), 71-80.

Sharma, Vibha. (2015). Understanding Child Trafficking and its Magnitude Department of Public Administration. International Journal of English Language, Literature, and Humanities, III(IV), 135-142.

Soraya, Anis, dkk. (2015). Perlindungan Terhadap Anak Korban Trafficking. Prosiding Penelitian dan Pengabdian Kepada Masyarakat, 2(1), 78-83.

Suhardin, Yohanes. (2008). Tinjauan Yuridis Mengenai Perdagangan Orang Dari Perspektif Hak Asasi Manusia. Mimbar Hukum, 20(3), 411-588.

Sumirat, Iin Ratna. (2017). Perlindungan Hukum terhadap Perempuan dan Anak Korban Kejahatan Perdagangan Manusia. Jurnal Studi Gender dan Anak, 3(1), 19-30. 
Yulia, Rena. (2016). Mengkaji Kembali Posisi Korban Kejahatan Dalam Sistem Peradilan Pidana. Mimbar Hukum, 28(1), 33-45.

Yuliartini, Ni Putu Rai. (2015). Kedudukan Korban Kejahatan Dalam Sistem Peradilan Pidana Di Indonesia Berdasarkan Kitab Undang-Undang Hukum Acara Pidana (KUHAP). Jurnal Komunikasi Hukum, 1(1), 81-94.

\section{Artikel Prosiding}

Anisa Soraya, D. (2020). Perlindungan Terhadap Anak Korban Trafficking. Riset Dan $P K M, 98$.

\section{Buku}

Arief, B. N. (1998). Beberapa Aspek Kebijakan Penegakan dan Pengembangan Hukum Pidana. Citra Aditya Bakti.

Cantrell, R. D. (2013). Modern Slavery: Investigating Human Trafficking. CreateSpace Independent Publishing.

Directorate, S. C. C.-T. C. E. (2019). Identifying and Exploring The Nexus Between Human Trafficking, Terrorism, and Terrorism Financing. United Nations Security Council.

Farhana. (2010). Aspek Hukum Perdagangan Orang di Indonesia. Sinar Grafika.

Gosita, A. (1993). Masalah Korban Kejahatan (Kumpulan Karangan). Akademik Presindo.

Hyun, S. K. (2018). Private International Law Issues on Cross-border Surrogacy Agreement under Korean Law. Kansai University.

Ibrahim, J. (2011). Teori dan Metodologi Penelitian Hukum Normatif. Bayu Media Publishing.

Jansson, D. B. (2014). Modern Slavery: A Comparative Study of the Definition of Trafficking in Persons. Martinus Nijhoff Publishers.

Marcellena Nirmala Chrisna Moeri, D. (2018). Implementasi Protokol Palermo Dalam Menanggulangi Permasalahan Tenaga Kerja Wanita Indonesia Yang Menjadi Korban Human Trafficking. Universitas Udayana.

Marzuki, P. M. (2005). Penelitian Hukum. Kencana Predana Media.

Muladi. (2002). Hak Asasi Manusia, Politik dan Sistem Peradilan Pidana. Badan Penerbit Universitas Diponegoro.

Pramono, M. A. dan B. A. (2011). Perdagangan Orang: Dimensi, Instrumen Internasional dan Pengaturannya di Indonesia. Citra Aditya Bakti.

Rakyat, K. K. B. K. (2004). Penghapusan Perdagangan Orang Trafficking in Person di Indonesia. Kemenkokesra.

Schafer, S. (1968). The Victims and His Criminal: A Study in Functional Responsibility. Random House. 
P-ISSN: 2656-534X, E-ISSN: 2656-5358

Jurnal Suara Hukum, Vol. 3, No. 1, Maret 2021

Sedletzki, V. (2008). Legislative Reform for the Protection of the Rights of Child Victims of Trafficking. UNICEF.

Supriyadi Widodo Eddyono, D. (2014). Masukan Terhadap Perubahan UU No. 13 Tahun 2006 tentang Perlindungan Saksi dan Korban. Koalisi Perlindungan Saksi dan Korban.

\section{Working Paper}

Tiefenbrun, Susan. 2007. Child Soldiers, Slavery, and the Trafficking of Children. 1020341. San Diego.

\section{Website}

Nations, United. 2016. "Report: Majority of Trafficking Victims Are Women and Girls; One-Third Children." Www.Un.Org 1.

Organization, International Labour. 2016. "Trafficking in Children.” Www.Ilo.Org 1. Retrieved September 29, 2020

(https://www.ilo.org/ipec/areas/Traffickingofchildren/lang--en/index.htm, diakses).

Puspita, Ratna. 2018. "KPAI Temukan 6 Kasus Dugaan Perdagangan Anak." Republika.Co.Id 1.

Putri, Budiarti Utami. 2020. "KPAI Temukan Dugaan Perdagangan Anak Di Tengah Pandemi Covid-19." Nasional.Tempo.Co 1. Retrieved September 10, 2020 (https://nasional.tempo.co/read/1337809/kpai-temukan-dugaan-perdagangan-anakdi-tengah-pandemi-covid-19/full\&view=ok).

UNICEF. 2007. "What Is the Convention on the Rights of the Child?" Unicef.Org 1. Retrieved September 30, 2020 (https://www.unicef.org/child-rightsconvention/what-is-the-convention). 